ISSN 0258-7122

Bangladesh J. Agril. Res. 35(1) : 167-177, March 2010

\title{
A STUDY ON THE AGRICULTURAL MECHANIZATION IN SELECTED FARMS OF THAKURGAON SUGAR MILL
}

\author{
MD. GOLAM FERDOUS CHOWDHURY ${ }^{1}$, MD. SARWAR HOSSAIN ${ }^{2}$ \\ M. A. SATTAR $^{3}$ AND MD. SHIRAZUL ISLAM ${ }^{4}$
}

\begin{abstract}
Mechanized cultivation plays significant role in sugarcane production in Bangladesh. A study was conducted in the Thakurgaon Sugar Mill farms in Thakurgaon District as an undergraduate project work in the Department of Farm Power and Machinery, Bangladesh Agricultural University, Mymensingh. The objective was to determine benefit-cost analysis of those farms. The farm management provided data on production cost and income for the year 20012002. On the basis of the supplied data, it was found that the three production farms were incurring loss and the experimental farm was found to be earning marginal profit. In this study, it was observed that the farms were spending huge amount on personnel and maintenance, which is probably peculiar nature of public enterprises. Bringing available land under production, adoption of more machines to reduce labour costs, and adoption of high yielding varietys appeared to be a partial solution to reduce the huge loss and to go for profit earning.
\end{abstract}

Keywords: Agricultural mechanization, farm implements, Thakurgaon Sugar Mill.

\section{Introduction}

Mechanization is a process through which agricultural activities can be improved and optimum crop production can be achieved. The mechanical inputs currently used in different farming activities in Bangladesh are pump for irrigation, power tiller and tractor, disc plough, disc harrow, subsoiler for tillage, weeder for weeding, sprayer for spraying pesticides, and thresher for threshing crops. The cropping intensity and production of food crops has recently been increased significantly due to adoption of mechanized tillage, irrigation, and spraying operations (Sarker, 2000).

Sugar is an important energy-supplying substitute in our dietary allowance. Sugar is produced mainly from sugarcane. Sugarcane was cultivated in an area of about 0.388 million acres (BBS, 2006) during 2004-2005. It was estimated to be about $2.15 \%$ of net cultivated area (BBS, 2006). The production of sugarcane is fluctuated from year to year due to fluctuation of area under sugarcane cultivation (Sheikh and Haque, 1986). The sugarcane production was highest

\footnotetext{
${ }^{1}$ Scientific Officer, Postharvest Technology Division, BARI, Joydebpur, Gazipur 1701, ${ }^{2}$ Assistant Engineer, BADC, Dinajpur Region, Dinajpur, ${ }^{3}$ Professor, Department of Farm Power and Machinery, BAU, Mymensingh, ${ }^{4}$ Assistant Engineer, Department of Agriculture Extension, Gabtoli, Bogra, Bangladesh.
} 
(4.70 million tons) in the year 1991 (Anon., 1991) and was lowest (1.04 million tons) in 1972 in the mill zone (Anon., 1973). The lowest yield of sugarcane was recorded in 1972 as 21.65 tons per hectare (Anon., 1973) and which had been increasing to 49.20 tons per hectare in the mill zone (Anon., 1991). However, yield and production could not be increased to the desired level due to various bottlenecks in production and marketing of sugarcane. There are 16 sugar mills in Bangladesh providing a large amount of sugar of our requirements. Among the Sugar Mills, Thakurgaon Sugar Mill plays a significant role in the local sugar production.

Different types of implements used in Thakurgaon Sugar Mill farms for sugar production. In the farm, subsoiler and riser (trencher) were not utilized due to 80-90 hp tractor. Thakurgaon Sugar Mill had 55-60 hp tractor. Salandar and Mohon farm applied fertilizer manually though those farms had drug buckets, but were not used due to lack of attachment implements with tractor. Bangladesh Sugarcane Research Institute (BSRI) had developed various types of low-cost seed cutting machines, but the farms had no seed cutting machine and harvester for sugarcane production. As a result, the farm spent much money for these purposes. In case of land preparation, these farms had a good number of tractors, compared with the tillage tools like disc plough and disc harrow. Salandar farm had five tractors, two disc ploughs, and two disc harrows. Mohon farm had six tractors, two disc ploughs, and one disc harrow. Jamalpur farm had four tractors, two disc ploughs, and one disc harrow and experimental farm had two tractors, one disc plough, and one disc harrow. As a result, most of the tractors remain inoperative due to lack of tillage tools. For irrigation, Salandar farm (108 ha) had six STWs and two DTWs though the average potential command area of these tube wells was 139.30 ha. Jamalpur farm (72 ha) had four STWs and one DTW and that covered to irrigate almost the whole farm (77.73 ha) successfully. Similarly experimental farm (24 ha) had only three STWs and it covered irrigation almost the whole farm (25.10 ha) successfully. But Mohon farm (100 ha) had five STWs and two DTWs which was sufficient for irrigation purpose for its 99.59 ha of land. The total cultivated area of these farms varied from 29 to $48 \%$ when the cultivable fallow area varied from 71 to $52 \%$. If these farms utilize all the available area for sugarcane production, then more machine/irrigation equipment will be required. These farms had various laps and gaps for sugarcane production. Therefore, the present study was undertaken as undergraduate research work in the Faculty of Agricultural Engineering and Technology, Bangladesh Agricultural University, Mymensingh to identify the major problems of production and marketing of sugar in Thakurgaon Sugar Mill under the division of Rajshahi. This paper will give a clear scenario of the status and constraints to mechanization in sugar mill farms during the study period. 
Table Al. Sugarcane production cost according to farm annual report 2001-2002.

\begin{tabular}{l|c|c|c|l}
\hline \multicolumn{1}{c}{ Description } & Salandar & Mohon & Jamalpur & Experimental \\
\hline Salary of wathman & 428605.00 & 720702.50 & 366007.00 & 268968.50 \\
Salary of field man & 289615.24 & 203925.25 & 179070.90 & 65222.50 \\
Salary of driver, foreman, fitter & 324948.94 & 405766.85 & 166878.25 & 187549.25 \\
Bonus & 202905.00 & 150320.00 & 107815.00 & 72430.00 \\
Fixed cost for implement & 572591.18 & 631231.45 & 418905.02 & 192795.59 \\
Total fixed cost (cost) & 1818665.36 & 2111946.05 & 1238676.17 & 786965.84 \\
Income (Tk.) & 4268359.00 & 2111946.05 & 1228676.17 & 786965.84 \\
Total cost (Tk.) & 5304449.24 & 4968006.00 & 3482503.48 & 1399604.24 \\
Total loss (Tk.) & 1036090.24 & 793111.69 & 628517.67 & 83012.50 \\
\hline
\end{tabular}

Table BI. Specification of implement in Salandar farm.

\begin{tabular}{|c|c|c|c|c|c|c|}
\hline Type & Model & HP & RPM & Brake type & Gear type & $\begin{array}{c}\text { Purchase } \\
\text { year }\end{array}$ \\
\hline Tractor & UMZ-6M 1977 & 55 & 1750 & Mechanical & Mechanical & 1978 \\
\hline Tractor & UMZ-6M 1984 & 60 & 1750 & Mechanical & Mechanical & 1985 \\
\hline Tractor & UMZ-6M 1988 & 60 & 1750 & Mechanical & Mechanical & 1988 \\
\hline Tractor & UMZ-6M 1991 & 60 & 1750 & Mechanical & Mechanical & 1991 \\
\hline Tractor & UMZ-6M 2000 & 60 & 1750 & Mechanical & Mechanical & 2001 \\
\hline $\begin{array}{l}\text { Disc } \\
\text { plough }\end{array}$ & $\begin{array}{l}\text { 54, Australia SI No. } \\
\text { J } 62520\end{array}$ & - & - & - & - & - \\
\hline Disc ploug & $\begin{array}{l}\text { 54, Australia Sl No. } \\
\text { J } 62521\end{array}$ & - & - & - & - & - \\
\hline $\begin{array}{l}\text { Disc } \\
\text { harrow }\end{array}$ & $\begin{array}{l}\text { LOD, PSF1O92E USA, } \\
\text { S1No. } 410\end{array}$ & - & - & - & - & - \\
\hline $\begin{array}{l}\text { Disc } \\
\text { harrow }\end{array}$ & $\begin{array}{l}\text { LOD, PSF1O92E USA, } \\
\text { SI No. } 411\end{array}$ & - & - & - & - & - \\
\hline
\end{tabular}

\section{Objectives of the study}

The objectives of the study were as follows:

i) to evaluate fixed cost, variable cost, and total cost of farm implements for sugar mill.

ii) to identity the laps and gaps of management system and suggest the remedies.

\section{Methodology}

Farm site: The study was aimed at assessing the status of agricultural mechanization in four selected farms of Thakurgaon Sugar Mill in Thakurgaon 
District. The selected farms were only operating at that period. The farms were Salandar, Mohon, Jamalpur, and Experimental.

Collection of data: A set of interview schedule was used for data collection. The interview schedule was prepared to collect relevant data related to farm implements. The data were collected during 2001-2002 (Appendix-I \& II).

Table A2. Cost analysis of various implements for different farms.

\begin{tabular}{|c|c|c|c|c|c|}
\hline Farm & Implement & $\begin{array}{l}\text { Depreciation } \\
\text { cost (Tk./yr) }\end{array}$ & $\begin{array}{l}\text { Interest } \\
(\mathrm{Tk} / \mathrm{yr})\end{array}$ & $\begin{array}{l}\text { Housing } \\
(\mathrm{Tk} / \mathrm{yr})\end{array}$ & $\begin{array}{c}\text { Total fixed } \\
\text { cost (Tk./yr) }\end{array}$ \\
\hline \multirow{5}{*}{ Salandar } & Tractor & 44000.00 & 28000.00 & 5000.00 & 385000.00 \\
\hline & Disc plough & 6733.00 & 5950.00 & 1100.00 & 27566.00 \\
\hline & Disc harrow & 7333.30 & 6500.00 & 1200.00 & 30066.60 \\
\hline & STW & 2071.43 & 1075.00 & 180.00 & 19958.58 \\
\hline & DTW & 23500.00 & 26500.00 & 5000.00 & 110000.00 \\
\hline \multirow{5}{*}{ Mohon } & Tractor & 44000.00 & 28000.00 & 5000.00 & 462000.00 \\
\hline & Disc plough & 6733.00 & 5950.00 & 1100.00 & 27566.00 \\
\hline & Disc harrow & 7333.30 & 6500.00 & 1200.00 & 15033.30 \\
\hline & STW & 2071.43 & 1075.00 & 180.00 & 16632.15 \\
\hline & DTW & 23500.00 & 26500.00 & 5000.00 & 110000.00 \\
\hline \multirow{5}{*}{ Jamalpur } & Tractor & 44000.00 & 28000.00 & 5000.00 & 308000.00 \\
\hline & Disc plough & 6733.00 & 5950.00 & 1100.00 & 27566.00 \\
\hline & Disc harrow & 7333.30 & 6500.00 & 1200.00 & 15033.30 \\
\hline & STW & 2071.43 & 1075.00 & 180.00 & 13305.72 \\
\hline & DTW & 23500.00 & 26500.00 & 5000.00 & 55000.00 \\
\hline \multirow{5}{*}{ Experimental } & Tractor & 44000.00 & 28000.00 & 5000.00 & 154000.00 \\
\hline & Disc plough & 6733.00 & 5950.00 & 1100.00 & 13783.00 \\
\hline & Disc harrow & 7333.30 & 6500.00 & 1200.00 & 15033.30 \\
\hline & STW & 2071.43 & 1075.00 & 180.00 & 99790.29 \\
\hline & DTW & 23500.00 & 26500.00 & 5000.00 & - \\
\hline
\end{tabular}

* Taking initial cost for tractor, disc plough, disc harrow, STW, DTW are 500000, 11000, 12000, 16000, 50000 Taka and salvage value 60000, 90000, 10000, 3500, 30000 Taka, respectively

Cost analysis: Cost analysis was done from field observations and cost records. Total cost was calculated from fixed and variable costs.

Fixed cost calculation: Fixed costs are expenses that occurred independent of use and variable cost occurred because of use. The fixed cost components considered were depreciation and interest. The depreciation cost was calculated 
using the equation, $\mathrm{D}=(\mathrm{P}-\mathrm{S}) / \mathrm{L}$, where, $\mathrm{P}$ is purchase price, $\mathrm{S}$ is salvage value, and $\mathrm{L}$ is the physical life in years. The physical life was assumed as 15 years. Interest was calculated by the formula, Interest $=10 \% \times \mathrm{P}$, where, $\mathrm{P}$ is the purchase price.

Table B2. Specification of implement in Mohon farm.

\begin{tabular}{ll|c|c|c|c|c}
\hline \multicolumn{1}{r}{ Type } & \multicolumn{1}{c|}{ Model } & HP & RPM & Brake type & Gear type & $\begin{array}{c}\text { Purchase } \\
\text { year }\end{array}$ \\
\hline Tractor & UMZ-6M 1993 & 55 & 1750 & Mechanical & Mechanical 1984 \\
Tractor & UMZ-6M 1984 & 65 & 1750 & Mechanical & Mechanical 1985 \\
Tractor & UMZ-6M 1987 & 65 & 1750 & Mechanical & Mechanical 1987 \\
Tractor & UMZ-6M 1988 & 65 & 1750 & Mechanical & Mechanical 1988 \\
Tractor & UMZ-6M 1991 & 55 & 1750 & Mechanical & Mechanical 1993 \\
Tractor & UMZ-6M 2000 & 60 & 1750 & Mechanical & Mechanical 2001 \\
Disc & 54, Australia Sl No. & - & - & - & - \\
plough & J 62522 & & & - & - \\
$\begin{array}{l}\text { Disc } \\
\text { plough }\end{array}$ & 54, Australia SI No. & - & - & - & - \\
$\begin{array}{l}\text { Disc } \\
\text { harrow }\end{array}$ & LOD23 & SI No. 412 & & & - & - \\
\hline
\end{tabular}

Variable cost calculation: The fuel, lubricants, operator, labour, and repair and maintenance cost were considered as variable cost components. Annual average fuel requirements for farm machinery depend on the annual use, for a particular enterprise. According to ASAE data D 230.1 (ASAE, 1968), average fuel consumption was calculated as $1.73 \times 0.06$ (PTO hp. Max), US Gal/hr. The cost of lubricants was proportional to the amount of fuel used and was taken as $15 \%$ of the fuel cost (ASAE, 1968). Labour charges were based upon the wage rates. For field operations, a machine needed at least one operator. The charges for unskilled labour, required to assist the operation, were also included in the cost of operation. Maintenance cost was included as the cost of all parts. Average repair cost, for any period of time was calculated by dividing the accumulated repairs in that time period by the hours of use which is shown as follows:

Rep (I) $=\frac{\text { Accumulated hours of use }}{\text { Total hours of use during the life }} \times \operatorname{RFV(I)}$

Where,

Rep (I) = Repair and maintenance cost at the end of year-I

RFV (I) = Remaining from values at the beginning year-I 
Total cost (without opportunity cost): Tcost $=$ Fixed cost + Variable cost Benefit-cost analysis: The benefit-cost analysis involved the quantification and costing of field inputs required for optimum crop performance and the determination of gross revenue, gross margin, and returns to risks and management based on expected yield. Break even point in the breakeven chart was the point at which total revenue (TR) and total cost (TC) were equal. Total cost above and below the point represented profit or loss, respectively.

Table B3. Specification of implement in Jamalpur farm.

\begin{tabular}{|c|c|c|c|c|c|c|}
\hline Type & Model & HP & RPM & Brake type & Gear type & $\begin{array}{c}\text { Purchase } \\
\text { year }\end{array}$ \\
\hline Tractor & UMZ-6M 1979 & 55 & 1750 & Mechanical & Mechanical & 1980 \\
\hline Tractor & UMZ-6M 1984 & 65 & 1750 & Mechanical & Mechanical & 1985 \\
\hline Tractor & UMZ-6M 1988 & 65 & 1750 & Mechanical & Mechanical & 1989 \\
\hline Tractor & UMZ-6M 1981 & 60 & 1750 & Mechanical & Mechanical & 1994 \\
\hline Disc plough & $\begin{array}{l}\text { 54, Australia } \\
\text { Sl No. J } 62524\end{array}$ & - & - & - & - & - \\
\hline Disc plough & $\begin{array}{l}\text { 54, Australia } \\
\text { SI No. J } 62525\end{array}$ & - & - & - & - & - \\
\hline Disc harrow & $\begin{array}{l}\text { LOD, PSF1092E } \\
\text { USA, SI No. } 413\end{array}$ & - & - & - & - & - \\
\hline
\end{tabular}

Table B4. Specification of implement in Experimental farm

\begin{tabular}{lllllll|l}
\hline \multicolumn{1}{c}{ Type } & \multicolumn{1}{c}{ Model } & HP & RPM & Brake type & Gear type & Purchase year \\
\hline Tractor & UMZ-6M 1979 & 50 & 1750 & Mechanical & Mechanical 1980 \\
Tractor & UMZ-6M 1986 & 65 & 1750 & Mechanical & Mechanical 1987 \\
Disc plough & 54, Australia & - & - & - & - & - \\
& Sl No. J 62554 & & & & - \\
Disc harrow & LOD, PSF1092E & - & - & - & - & - \\
& USA, SI No. 425 & & & & \\
\hline
\end{tabular}

\section{Limitations of the study}

1. Inflation, during the useful life of the machine has not been taken into account.

2. The farms of the Thakurgaon Sugar Mill are big enough for collection of data accurately. So, the information is given by management had been analyzed.

3. Assuming that increasing area under cultivation would distribute the fixed cost on more areas, but the other variable costs would increase proportionately. 


\section{Results and Discussion}

Benefit-cost analysis of different farms: Three agricultural farms, i.e, Salandar farm, Mohon farm, Jamapur farm and one Experimental farm were 139.30, 99.59, 77.73, and 25.10 ha, respectively. The available data on income and expenditures for the year 2000-2001 showed that the three commercial farms incurred huge loss and the experimental farms incurred less loss. But the area of experimental farm was too small and its impact on the gross production system was little. The total production system suffered huge loss. In this study, an effort was made to find ways how to earn profit or to minimize loss on the farms on the basis of their available resources. The strategies considered for analysis were to go for fill production of the available areas of the respective farms. It was assumed that the overhead and management costs will remain constant whether the farms were producing or not. Increasing area under cultivation will distribute the fixed cost on more areas, but the other variable cost will increase proportionately.

Figure 1 shows that the Salandar farm had 292.70 ha, where 139.30 ha was cultivated. So, the total variable cost, total fixed cost, total cost and, revenue were 25094, 13063, 38079, $30641 \mathrm{Tk} / \mathrm{ha}$, respectively. The variable cost was increased proportionality and it was same. The fixed cost will remain constant for 100, 200, 300, 400, 500, and 600 ha of land and it was $18197 \mathrm{Tk} / \mathrm{ha}$. But the total cost (Tk/ha) will be decreased and it will be 43290, 34192,31159,29643,28733, 28126 $\mathrm{Tk} / \mathrm{ha}$, respectively. It was found that if the farm cultivated whole of the land then the difference between total cost and the revenue would be less and the huge loss being incurred would be reduced.

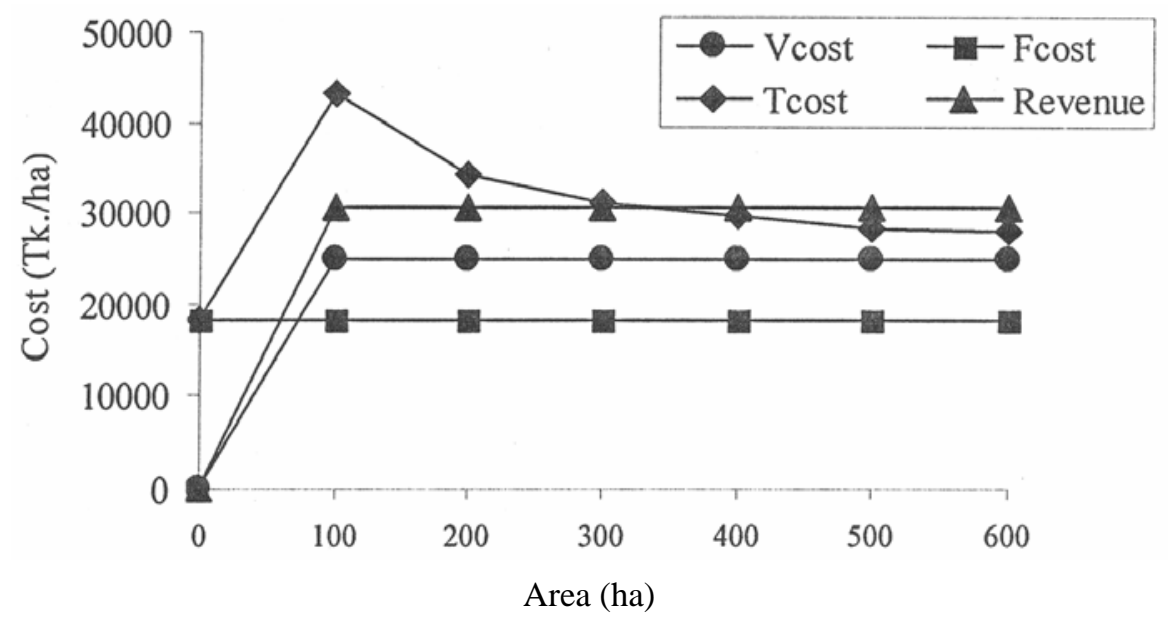

Fig. 1. Benefit-cost relationship of Salandar farm.

Figure 2 shows that the Mohon farm had cultivable area 331.58 ha, where 99.59 ha was cultivated. Here the total variable cost, total fixed cost, total cost, and 
revenue were 28678, 21206, 49885, $41921 \mathrm{Tk} / \mathrm{ha}$, respectively. At this condition, the total cost was high and revenue was low and the production system incurred loss. The variable cost was increased proportionality. The fixed cost will remain constant for 100, 200, 300, 400, 500, and 600 ha of land and it was $21129 \mathrm{Tk} / \mathrm{ha}$. But the total cost (Tk/ha) will be decreased and it was 49808, 39243, 35721, 33961, 32904, 32200 TK/ha, respectively. On this basis, it was found that if the farm cultivated more than 175 ha of land than the revenue line would cross the total cost line and the farm would earn profit within the available resources.

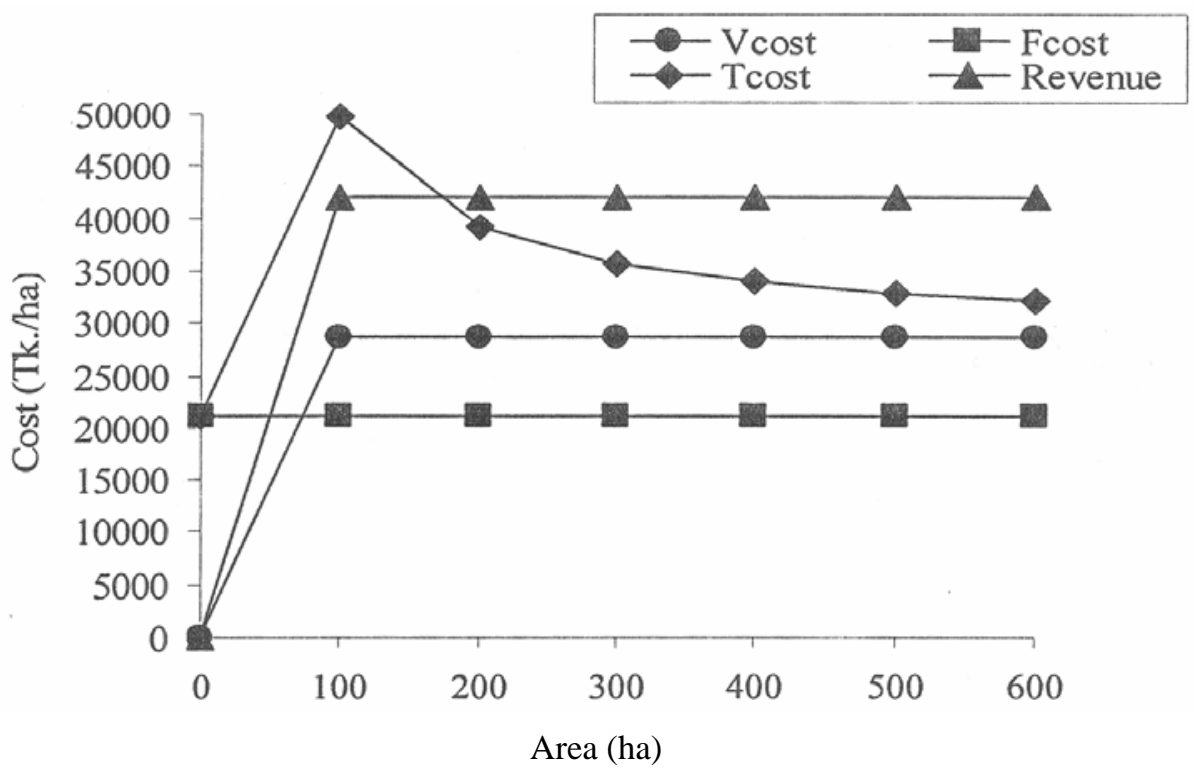

Fig. 2. Benefit-cost relationship of Mohon farm

Figure 3 shows that the Jamalpur farm had cultivable area 210.90 ha, but 77.70 ha was cultivated. Here the total variable cost, total fixed cost, total cost, and revenue were 28996, 15807, 44803, $36717 \mathrm{Tk} / \mathrm{ha}$, respectively. At this condition, the total cost was high and revenue was low and the production system incurred loss. The variable cost was increased proportionately. The fixed cost will remain constant for 100, 200,300, 400, 500, and 600 ha of land and it was $12287 \mathrm{Tk} / \mathrm{ha}$. But the total cost (Tk/ha) will be decreased and it was 41282, 35139, 33091, 32067, 31453, $31043 \mathrm{Tk} / \mathrm{ha}$, respectively. It was observed that if the farm cultivated more than 170 ha of land then the revenue line would cross the total cost line and the farm would earn profit within the available resources. 


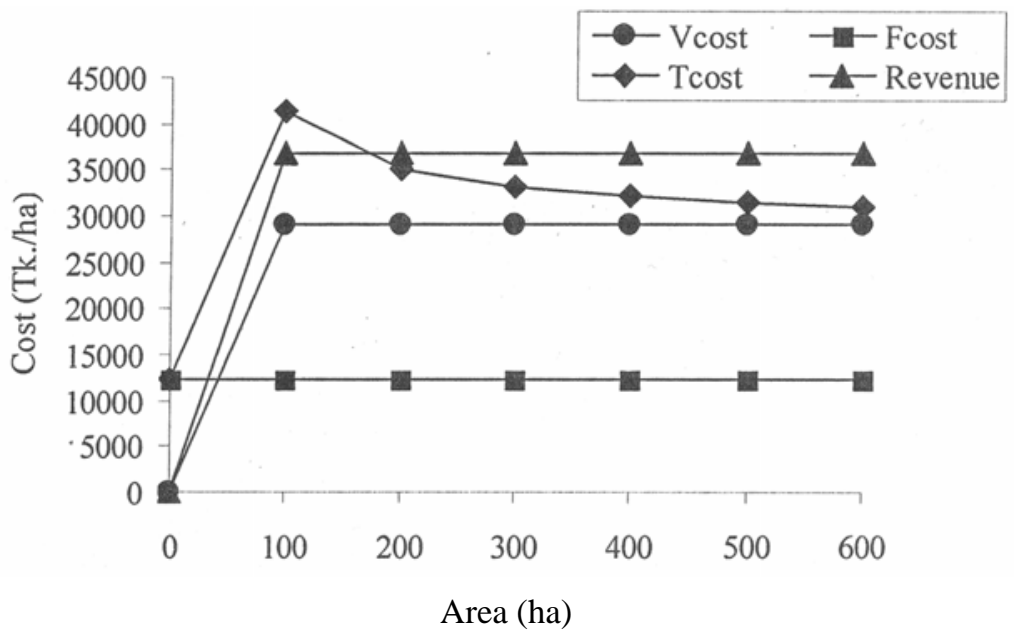

Fig. 3. Benefit-cost relationship of Jamalpur farm

Figure 4 shows that the experimental farm had cultivable area 87.85 ha, but 25.10 ha was cultivated. Here the total variable cost, total fixed cost, total cost, and revenue were 24408, 31353, 55761, $52454 \mathrm{Tk} / \mathrm{ha}$, respectively. At this condition, the total cost was high and revenue was low and the production system incurred loss. The variable cost will be same and the fixed cost will remain constant for $100,200,300,400,500$, and 600 ha of land and it was $7870 \mathrm{Tk} / \mathrm{ha}$. The total cost (Tk./ha) will be decreased and it was 32278, 28343, 27031, 26375, 25982, 25720 $\mathrm{Tk} / \mathrm{ha}$, respectively. It was observed that if the farm cultivated more than 30 ha of land then the revenue line would cross the total cost line and the farm would earn profit within the available resources.

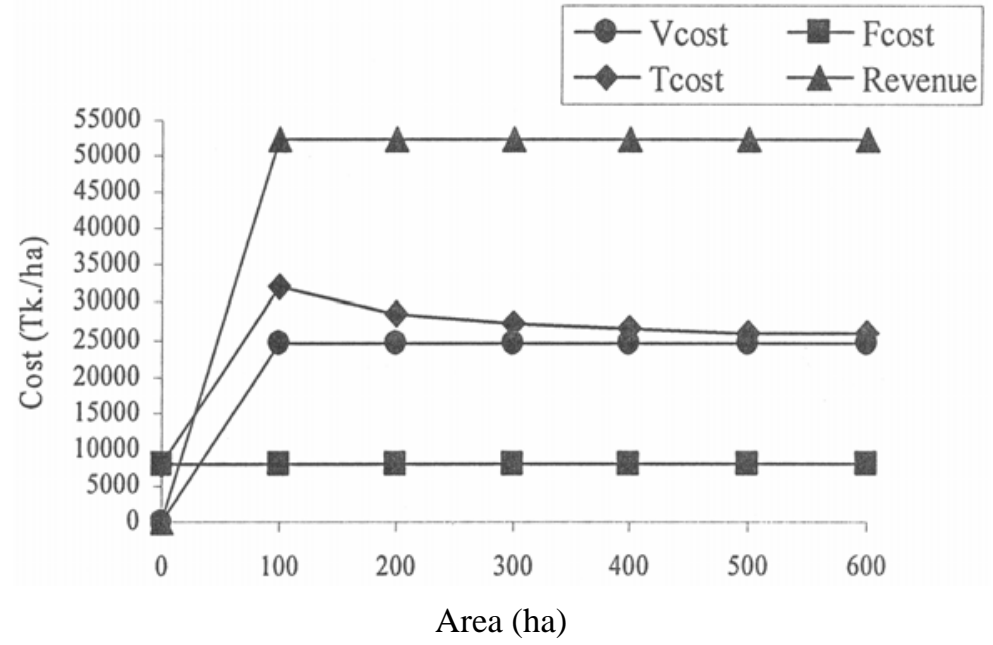

Fig. 4. Benefit-cost benefit relationship of fcperimental farm. 
Cost and revenue analysis of different farms: Figure 5 shows that the highest mechanization cost was 38\% in Mohon farm of the total mechanization cost of the farm. Salandar, Jamalpur, and Experimental farm were 30\%, 22\%, 10\%, respectively of the total mechanization cost of the farms. Figure 6 shows that the highest revenue was 34\% in Salandar farm, second highest was in Mohon farm (33\%) and others were $23 \%$ and $10 \%$ of the total revenue of the farms.

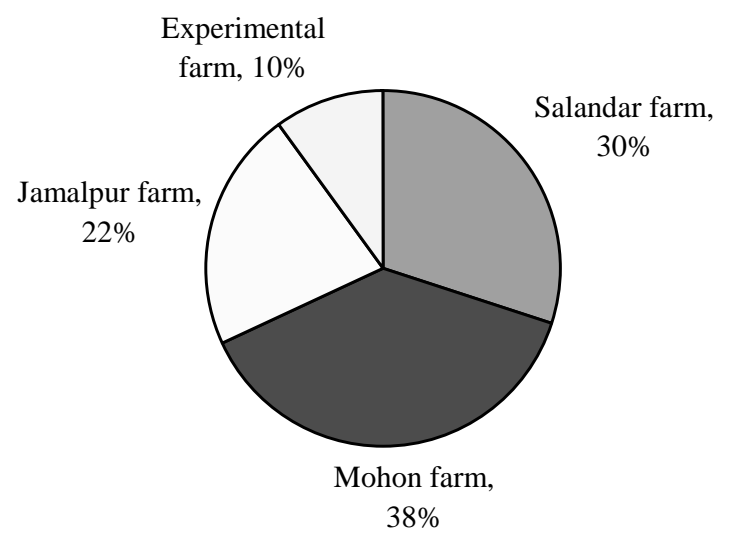

Fig. 5. Percentage of mechanization cost in different farms.

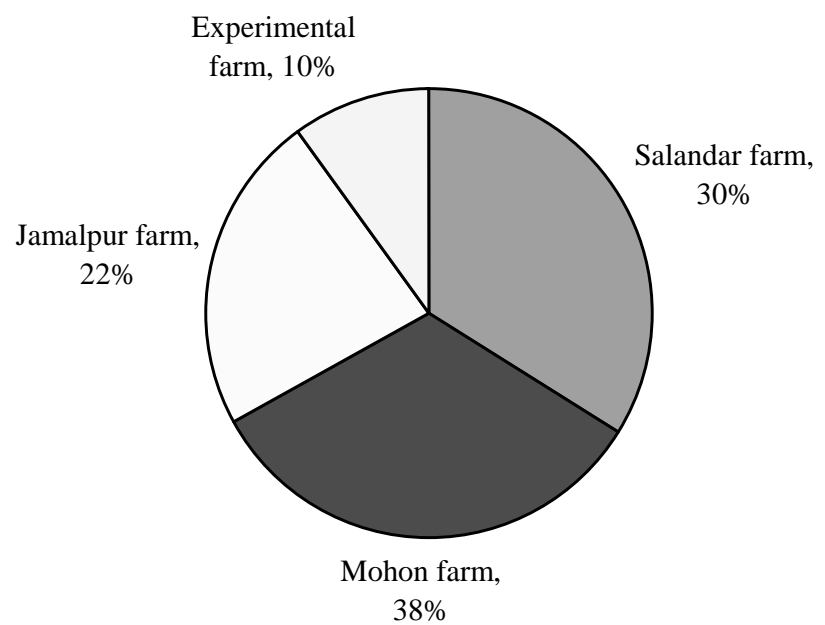

Fig. 6. Percentage of revenue of different farms. 


\section{Conclusion}

It was observed that the Salandar farm had 292.70 ha of cultivable area, but they cultivated only 139.30 ha. At that condition, the difference between total cost and revenue was very high. If the farm cultivated whole of the land than the difference between the total cost and revenue would be less and the huge loss being incurred would be reduced. The Mohon farm had cultivable area of 331.58 ha, but it cultivated only 99.59 ha. So, the total cost was high and revenue was low and the production system incurred loss. If the farm cultivated more than 175 ha of land the farm will earn profit. Adoption of mechanization of the production system will reduce the excess cost and the farm would be profitable. The Jamalpur farm had cultivable area 210.90 ha, but they cultivated only 77.73 ha. If the farm cultivated more than 170 ha of land then the revenue line would cross the total cost line. So, the farm would earn profit by increasing the cultivated area. The experimental farm had 87.85 ha of cultivable area, but they cultivated only 25.10 ha. The total cost of the farm was $1399604 \mathrm{Tk}$ and revenue was $1316592 \mathrm{Tk}$. So the farm was in loss condition. If the farm cultivated more than 30 ha of land then the revenue line would cross the total cost line and then the farm would be profitable. Thakurgaon Sugar Mill was a public enterprise. The high overhead and management costs were probably lied with the peculiar characteristics of the public enterprises. Even the variable costs appeared to be high.

\section{References}

Anonymous, (BSMC Annual Report). 1972-73. Bangladesh Sugar and Food Industries Corporation, Dhaka: MIS and Computer Division (BSFIC). p.28.

Anonymous, (Barshik Protebedan). 1990-91. Bangladesh Sugar and Food Industries Corporation. Dhaka, MIS and Computer Division (BSFIC). p.13.

ASAE. 1968. Year Book of ASAE, ST. Joseph, Michigan, USA.

BBS. 2006. Statistical Year Book of Bangladesh. Bangladesh Bureau of Statistics. Statistics Division, Ministry of Planning. Government of the People's Republic of Bangladesh.

BSFIC. 2001. Annual Budget of Thakurgaon Sugar Mill, 2000-2001. Thakurgaon.

Sarker, M.R.L 2000. Energy use pattern in small farm system of Bangladesh. Journal of Agricultural Machinery and Mechanization. 4(1): 29-44.

Sheikh, M.N. and M.M. Haque. 1986. Production consumption and demand for sugar in Sugar Industry in Bangladesh Eds. Shalauddin et. al., BSFIC, Shilpa Bhaban, Motijheel Commercial Area, Bangladesh. pp. 51-52. 